\title{
Truth and Truthmakers in Early Modern Scholasticism
}

[Penultimate Draft]

Abstract: $17^{\text {th }}$-century Iberian and Italian scholastics had a concept of a truthmaker [verificativum] similar to that found in contemporary metaphysical debates. I argue that the $17^{\text {th }}$-century notion of a truthmaker can be illuminated by a prevalent $17^{\text {th }}$-century theory of truth according to which the truth of a proposition is the mereological sum of that proposition and its intentional object. I explain this theory of truth and then spell out the account of truthmaking it entails.

Keywords: Truthmaker, Truth, Denomination, Early Modern Scholasticism, Rodrigo de Arriaga

At a first approximation, a truthmaker is something responsible for the truth of a proposition. The idea that truths are made true by portions of reality has been used in recent years to "regiment metaphysical enquiry" (Armstrong 2004: 4). The idea is that asking what makes certain truths true is a good way to find out what our ontological commitments are. The notion of a truthmaker has recently gained such prominence in metaphysics that Gonzalo Rodriguez-Pereyra has called truthmaker theory "one of the most important metaphysical topics of the late $20^{\text {th }}$-century and early $21^{\text {st }}$-century philosophy" (Rodriguez-Pereyra 2006: 186).

What few have noticed is that the notion of a truthmaker made a sudden appearance on the philosophical scene of $17^{\text {th }}$-century Iberian and Italian scholasticism, and it played an important role in a variety of ontological disputes. ${ }^{1} 17^{\text {th }}$-century scholastics coined the term 'verificativum', which is the Latin equivalent of our 'truthmaker.' It is clear from the ways in which early modern scholastics use the term 'verificativum' that, like

This paper has benefited from careful reading and helpful comments by Megan Embry, John Heil, Sydney Penner, Martin Pickavé, and Marleen Rozemond. I presented some of this material at the 2014 Toronto Colloquium for Mediaeval Philosophy.

${ }^{1}$ John Doyle was the first (in print) to suggest 'truthmaker' as a translation of 'verificativum' (Doyle 1995: 773 , fn. 12). For a helpful survey of some of the $17^{\text {th }}$-century literature on truthmakers, see Schmutz (2011: 739-748) and Ramelow (1997: 230-241). The Schmutz paper initially sparked my interest in early modern scholastic theories of truthmaking. 
contemporary philosophers, they conceive of truthmakers as portions of reality responsible for the truth of propositions. Here, for example, are some sightings of 'verificativum' (translated as 'truthmaker') in the wild:

The immediate and formal truthmaker of a proposition is that in virtue of which a proposition is immediately and formally rendered true. ${ }^{2}$

The objective, formal, and immediate truthmaker of any act is that which the act expresses $[\ldots]$ and which is such that by its mere existence the act is true (if the act exists) $[\ldots]^{3}$

The formal truthmaker of any judgment is that by which the act is rendered formally true. ${ }^{4}$

As is clear from these passages, early modern scholastics have a variety of names for truth-bearers, including 'proposition', 'act', and 'judgment'. I will say more about these different terms for truth-bearers below. For now I want to point out that, whatever truthbearers are, it seems clear from the above passages that some early modern scholastics conceive of a truthmaker as a portion of reality that is somehow responsible for the truth of a proposition.

It is also clear that early modern scholastics used the notion of a truthmaker to "regiment metaphysical enquiry". More specifically, scholastics had debates about truthmakers for negative truths, tensed truths, and modal truths. In the following passage, for example, Giovannbattista Giattini uses a truthmaker argument to establish the existence of negative entities:

It seems like you have to say that there are negations in reality and that negations have some objective truth distinct from every real positive being. This conclusion is proven because there must be a formal truthmaker for a negative proposition-e.g., for the proposition by

\footnotetext{
${ }^{2}$ Peinado, Disputationes in octos libros physicorum, 177.12: "Verificativum immediatum \& formale propositionis, est id a quo propositio immediate \& formaliter redditur vera." All translations in the paper are my own. With the exception of Suárez's texts, early modern scholastic texts are cited by page number and paragraph number where available: 1.2 = page 1, paragraph 2 . In the Latin texts I alter the original punctuation where doing so makes the sentence structure more perspicuous.

${ }^{3}$ Madritano, Prodromus, 775.52: "Verificativum obiectivum, formale, ac immediatum cuiuslibet actus est illud, quod actus enunciat ( $\mathrm{Si}$ enim per actum non enunciatur erit ad summum verificativum illativum) quodque est tale, ut, ipso solo existente, actus sit verus, si hic quoque existat, \&, ipso non existente, actus sit falsus."

${ }^{4}$ Anonymous, Disputatio de obiecto et verificativo propositionum, f. $217 \mathrm{v}$ : "Verificativum formale alicuius iudicii est illud a quo actus redditur verus formaliter."
} 
which I say "Light is not in the air". But this truthmaker is not something positive. Therefore, it is a negation, distinct from everything positive. ${ }^{5}$

Maximus Mangold raises a standard truthmaking question in his discussion of future contingent truths:

Further, it is asked in virtue of what are [future contingent propositions] true? Or, what is their truthmaker, as they say in the school. ${ }^{6}$

And in the following passage Nicholas Martinez reports an argument to the effect that God is the truthmaker for modal truths:

This proposition, 'Peter is possible' is true, and necessarily true; therefore, it is true in virtue of its necessary truthmaker. Nothing created is necessary, and whatever is necessary is God. Therefore, this proposition is true in virtue of its truthmaker, which is God. ${ }^{7}$

In short, in light of these passages it seems clear that early modern scholastics had the notion of a truthmaker, and that this notion plays a role in their ontological enquiry. But it is not immediately clear what the early modern scholastic account of truthmaking is, nor indeed whether there is just one account or many. The early modern scholastic literature on truthmaking is rich and extensive, and I cannot hope to explain or even mention all of it here. My limited aim is to explain one apparently prevalent $17^{\text {th }}$-century account of truthmaking, an account entailed by what I call the "semi-extrinsic denomination view of truth". In section one I explain the semi-extrinsic denomination view of truth. In section two I establish the relationship between the semi-extrinsic denomination view of truth and the notion of a truthmaker. In section three I spell out the account of truthmaking entailed by the semi-extrinsic denomination view of truth.

\footnotetext{
${ }^{5}$ Giattini, Logica, 265: "Dicendum videtur negationes dari a parte rei, \& habere aliquam veritatem obiectivam distinctam ab omni ente reali positivo. Probatur conclusio, quia debet dari verificativum formale propositionis negativae qua v.g. dico, in aere non est lux. Sed hoc verificativum non est quid positivum, ergo est negatio distincta ab omni positivo."

${ }^{6}$ Mangold, Philosophia recentior, vol. 1, 96.98: "Ulterius quaeritur, per quid verae aut falsae sint [propositiones de contingentibus absolute futuris]? Sive, quodnam sit illarum verificativum, ut loquuntur scholae."

${ }^{7}$ Martinez, Deus sciens, 73: "Propositio haec: Petrus est possibilis, est vera, \& necessario vera, ergo per aliquod verificativum illius necessarium: nihil necessarium est creatum, \& quidquid necessarium est Deus est. Ergo haec propositio vera est per verificativum illius, quod Deus est."
} 


\section{Truth as a Semi-Extrinsic Denomination}

The semi-extrinsic denomination view of truth has its origin in some aporetic remarks made by Francisco Suárez. In the second section of his disputation on truth, Suárez addresses the question, 'What is the truth of a cognition? ${ }^{8}$ Here Suárez has in mind a particular kind of cognition - namely, the so-called act of composing and dividing. Almost all early modern scholastics conceive of primary truth-bearers as mental acts. ${ }^{9}$ These mental acts go by various names, including 'proposition', 'judgment', 'affirmation', 'cognition', 'mental act', and sometimes just 'act'. (Some of these terms can be seen in the quotations provided above). Going forward I will arbitrarily adopt the term 'proposition' for the relevant truth-bearing mental acts, but these should not be confused with Fregean propositions, which are not mental acts but abstract entities. Early modern scholastics had further debates about the structure of propositions, but for our purposes we may set these debates aside and conceive of propositions roughly as mental sentences. ${ }^{10}$ At any rate, Suárez's question in Metaphysical Disputations, section 2, disputation 8 is, what sort of thing is propositional truth? Is truth a relation? A property? A being of reason? Or something else entirely?

After arguing that truth is neither a property nor a relation nor a being of reason, Suárez defends the following two obscure claims about truth:

(1) Truth adds nothing real and intrinsic to a proposition but connotes an object that is as represented by the true proposition. ${ }^{11}$

(2) Truth includes (i) a representation and (ii) an object as represented by the representation. $^{12}$

\footnotetext{
${ }^{8}$ Metaphysical Disputations (DM) 8.2 (XXV, 277ff.). DM is cited by disputation, section, and paragraph number where appropriate, with volume and page numbers in parentheses.

${ }^{9}$ One exception can be found in Vázquez, Commentariorum ac disputationum in primam partem Sancti Thomae tomus primus, 294.3. Suárez discusses Vázquez's view in DM 8.2.

${ }^{10}$ For extensive discussion of these debates, see Izquierdo, Pharus scientiarum, 82ff. For Suárez's own view, see De anima 3.6 (III, 637ff.)

${ }^{11}$ See Suárez, DM 8.2.9 (XXV, 279): "Veritatem cognitionis ultra ipsum actum nihil addere reale et intrinsecum ipsi actui, sed connotare solum obiectum ita se habens sicut per actum repraesentatur."

${ }^{12}$ See Suárez, DM 8.2.12 (XXV, 280): "Ex dictis concludo veritatem cognitionis includere talem repraesentationem cognitionis quae habeat conjunctam conformitantiam obiecti ita se habentis, sicut per cognitionem repraesentatur. Probatur ex dictis, quia ad veritatem nec sola repraesentatio sufficit, si
} 
Going forward it will be important to keep in mind that for early modern scholastics the term 'object' means 'intentional object'. It was a matter of some debate what exactly the intentional object of a proposition is, but for the sake of illustration it is worth pointing out that early modern scholastics often speak of the object of a proposition of the form ' $a$ is F' as $a$ 's Fness or the identity between $a$ and Fness. ${ }^{13}$ Even so, it is not immediately clear what claims (1) and (2) mean. Nor is it clear which claim, (1) or (2), represents Suárez's answer to the question, what sort of thing is propositional truth? Suárez's lack of clarity on this question led to a further debate about the proper interpretation of Suárez and about the nature of truth.

Writing on truth about 50 years after the publication of Suárez's Metaphysical Disputations, Sebastián Izquierdo begins his disputation on truth with a literature review. He lists the views rejected by Suárez, and then he adds Suarez's view to the list: "Suárez himself (see [d. 8] n. 9) says that truth adds nothing intrinsic to the cognition, but only connotes an extrinsic object." But, Izquierdo adds, "This can be understood in two ways. Either truth consists entirely in the cognition, with the object posited as a connoted condition that is entirely extrinsic to the proposition [...] or truth includes both the cognition and the object in its concept." ${ }^{14}$ Izquierdo goes on to endorse the second interpretation of Suárez's remarks on truth, which he explains as follows:

And so [truth] is partly intrinsic to a cognition and partly extrinsic. This is the view of Arriaga, Oviedo [...] and others, and among our contemporaries it is the common way of philosophizing concerning semi-extrinsic denominations. ${ }^{15}$

obiectum non ita se habeat sicut repraesentatur: neque concomitantia obiecti potest sufficere ad denominationem veritatis, nisi praesupposita praedicta repraesentatione vel potius includendo illam; quia veritas non est sola illa denominatio extrinseca, sed includit intrinsecam habitudinem actus terminatam ad obiectum taliter se habens."

${ }^{13}$ Giattini, Logica, 292; Polizzi, Philosophicarum disputationum tomus tertius, 669.168; Peinado, De anima, 265.32; Arriaga, Cursus philosophicus, 170.27.

${ }^{14}$ Izquierdo, Pharus scientiarum, 110.4: "Ipse Soar. n. 9. nihil addere actui cognitionis intrinsecum; sed tantum connotare obiectum extrinsecum. Quod bifariam potest intelligi, aut quod veritas adaequate consistat in cognitione posito obiecto ut conditione omnino extrinsece connotata, \& ita opinantur, philosophanturque nonnulli, aut quod veritas utrumque complectatur in suo conceptu \& cognitionem \& obiectum."

${ }^{15}$ Izquierdo, Pharus scientiarum, 110.4: “Atque adeo partim sit intrinseca cognitioni, partim extrinseca: \& ita censent Arriaga, Oviedo, Franc. Alf. \& alii. Estque inter Recentiores communis modus philosophandi circa denominationes semiextrinsecas." 
In addition to claiming that truth is partly intrinsic and partly extrinsic to a true proposition, Izquierdo tells us that the notion of a "semi-extrinsic denomination" is somehow relevant to the theory of truth in question. (Hence, the "semi-extrinsic denomination view of truth".) Izquierdo also tells us that the view in question was endorsed by Rodrigo de Arriaga and Francisco Oviedo. In order to get a better grasp of the theory of truth in question, I want to turn now to Arriaga.

In his disputation on truth, Arriaga endorses the following view:

Our conclusion is this: Truth consists in a denomination that is partly intrinsic to the proposition and partly extrinsic: intrinsic insofar as it posits [dicit] the proposition itself affirming [for example] the running of Peter, but extrinsic insofar as it posits the object itself existing in the way [eo modo] in which it is affirmed by the proposition. ${ }^{16}$

This passage clarifies how the notion of a denomination is involved in Arriaga's theory of truth. According to Arriaga, truth is a denomination that is partly intrinsic and partly extrinsic to a true proposition. In order to clarify this view of truth, we need to take a detour through the notion of a denomination.

The notion of a denomination is ubiquitous in early modern scholasticism (Doyle 1984). A denomination involves three items: a subject (or, as Giuseppe Polizzi says, a "quasi-subject"; more on this qualification shortly), a denominating form, and a denominative name. The denominative name is used to denominate the subject because of a denominating form. For instance, suppose our denominating name is 'white', our subject is Socrates, and our denominating form is Socrates' whiteness. The idea is that we use the name 'white' to denominate Socrates because of Socrates' whiteness.

Denominations can be intrinsic, extrinsic, or semi-extrinsic. ${ }^{17} \mathrm{~A}$ denomination is intrinsic if the denominating form is intrinsic to (or identical with) the subject. An example of an intrinsic denomination is given in the proposition 'Socrates is white' because Socrates' whiteness is intrinsic to Socrates. A denomination is extrinsic if its denominating form is extrinsic to the subject. Common examples of extrinsic

\footnotetext{
${ }^{16}$ Arriaga, Cursus philosophicus, 170.23: "Nostra conclusio est, Veritas consistit in denominatione partim intrinseca propositioni, \& partim extrinseca. Intrinseca, quatenus dicit ipsam propositionem affirmantem cursum Petri: extrinseca vero, quatenus dicit ipsum obiectum eo modo existens, quo per propositionem affirmatur." See also the rest of subs. 5.

${ }^{17}$ See Izquierdo, Pharus scientiarum, 297-298.42; Oviedo, Tomus II philosophiae, 361.1.
} 
denominations include being cognized and being seen: the terms 'cognized' and 'seen' apply to Socrates (say) because of cognitive and perceptual episodes extrinsic to Socrates (assuming that Socrates is not thinking about or looking at himself). The contemporary concept of a Cambridge property does the work of the early modern scholastic concept of an extrinsic denomination. Finally, a denomination is semi-extrinsic if its denominating form is partly intrinsic and partly extrinsic to the subject. We will see how this works in the case of truth.

Some clarifications about denominations are in order. We can now see why Polizzi calls the subject of a denomination a "quasi-subject." In some cases, the subject of a denomination is a subject in the proper sense-Socrates, for example, is properly the subject of whiteness because whiteness inheres in Socrates. For extrinsic and semiextrinsic denominations, however, this is not the case. Socrates is not properly the subject of the cognitive episode in virtue of which he is thought about, nor is he the subject of the perceptual episode in virtue of which he is seen. It is for this reason that some philosophers call the subject of a denomination the 'thing denominated', a phrase with less metaphysical baggage than 'subject'. A second important terminological clarification is that a denominating form need not actually be a form. It can be anything of any ontological category.

I have explained the notion of a thing denominated, a denominating form, and a denominative name. But I have not yet explained denomination itself. What exactly is a denomination? When Arriaga says that truth is a denomination, with what sort of thing is he identifying truth? It is perhaps natural to think that a denomination is something linguistic. This sort of interpretation can be found in the secondary literature. For example Jorge Gracia and Daniel Novotný write,

Stated simply, "to denominate" means "to name a thing derivatively." More precisely, a denomination is the substitution of the name N2 of a thing T2 for the name N1 of another thing T1 to which T2 is somehow related. [Gracia and Novotný 20011: 27].

Here denomination is supposed to be the act of substituting one name for another. This is a linguistic phenomenon. Similarly, Christopher Shields writes, 
An extrinsic denomination of $a$ is some predicate, being- $\phi$, which $a$ bears non-intrinsically. [Shields 2012: 67]

Here an extrinsic denomination is conceived of as a predicate - a piece of language. (It is unclear how something can bear a predicate, much less bear a predicate non-intrinsically, but that is another problem). Finally, in his landmark article on extrinsic denominations in Suárez, John Doyle writes,

Let me provisionally describe extrinsic denomination as a designation of something, not from anything inherent in itself, but from some disposition, coordination, or relationship which it has toward or with something else. [Doyle 1984: 122-123]

Here Doyle explains that a denomination is a designation of something, designation presumably being a linguistic phenomenon. In fairness, it should be noted that Doyle goes on to revise this provisional characterization for reasons I will now explain.

What some commentators seem to overlook is that there was a debate among early modern scholastics about the ontological status of denominations. Some philosophers did indeed endorse a view of denominations close to that suggested in the above passages. Gabriel Vázquez, Suárez’s philosophical rival, writes,

I think that before the operation of the intellect there is no real denomination from some thing or from an extrinsic form. For because denomination is the appellation of a name, it is the work of reason [...] Hence, to concede that there is some real extrinsic denomination before any act of the intellect implies a contradiction in the object. For if it is a denomination, it is the expression of some intellect [my emphasis]. ${ }^{18}$

In this passage Vazquez makes two claims. First, he says that denominations are not real, by which he means that they are mind-dependent. The reason for this, and his second claim, is that a denomination is the "appellation of a name" or the "expression of some intellect". So this passage seems to support the idea that a denomination is a linguistic phenomenon of some sort. I'll call this the 'anti-realist conception' of denominations. It

\footnotetext{
${ }^{18}$ Vázquez, Commentariorum ac disputationum in primam partem Sancti Thomae tomus secundus, 32.2: "Secundo existimo, ante intellectus operationem non esse realem aliquam denominationem ab aliqua re, aut forma extrinseca. Quia denominatio, cum sit nominis appellatio, est etiam opus rationis, et res quae absoluta in se est, si relate denominatur, ab intellectu relate eam concipiente denominatur: nomina enim a nobis imposita sunt, ut id quod de rebus concipimus, significemus: quare concedere denominationem aliquam extrinsecam realem ante quemcumque intellectum, contradictionem implicat in obiecto: nam si est denominatio, est alicuius intellectionis expressio."
} 
is striking that when paired with the semi-extrinsic denomination view of truth, the antirealist conception of denominations entails that truth is a mind-dependent linguistic phenomenon.

Although the anti-realist conception of denominations is perhaps the natural one, and it is clearly supported by the above text from Vázquez, other early modern scholastics argue that denominations are mind-independent realities rather than linguistic phenomena. This can be seen clearly in the following passage from Suárez. Here Suárez is considering the question whether extrinsic denominations are beings of reason, and his primary opponent appears to be Vázquez:

If a denomination is taken from a real form, by this very fact it exists in reality, and consequently it does not pertain to beings of reason. The antecedent is clear because that form has true real being without dependence on reason. Therefore the denomination coming from that form is also real, although it is extrinsic, and it does not have being merely objectively in the intellect or in virtue of some activity or fiction of the intellect. ${ }^{19}$

Here Suárez claims that a denomination is real if the denominating form from which it is taken is real. In the next passage, Suárez directly confronts Vazquez's view of denominations:

You will say, because it is merely a denomination, it cannot be more than a being of reason, for denomination is the work of reason. I respond: if by 'denomination' someone were to understand the imposition of a denominative name, that indeed is a work of reason. But now we are not concerned about the imposition of a denominative name, for in this way even an intrinsic denomination is a work of reason, considered as an imposition of a denominative name. But we are concerned with the unions and relations [habitudinibus] of things themselves, in which such denominative names are grounded. These are not works of reason. $^{20}$

\footnotetext{
${ }^{19}$ Suárez, DM 54.2.10, (XXVI, 1020): "Si denominatio sumitur a forma reali, hoc ipso in rebus existit, et consequenter non pertinet ad entia rationis. Antecedens patet quia illa forma habet verum esse reale sine dependentia a ratione; ergo etiam denominatio ab illa proveniens, quamvis extrinseca, realis tamen est, et non est tantum obiective in intellectu, aut per negotiationem aut fictionem eius." See also Suárez, DM 54.2.14, (XXVI, 1021).

${ }^{20}$ Suárez, DM 54.2.10, (XXVI, 1020): "Dices: hoc ipso quod est sola denominatio, non potest esse plus quam ens rationis, nam denominatio opus rationis est. Respondetur: si per denominationem quis intelligat impositionem nominis denominativi, illud quidem est opus rationis. Sed nunc non agimus de impositionem nominis denominativi, hoc enim modo etiam denominatio intrinseca, quantum ad impositionem nominis denominativi, est opus rationis. Sed agimus de ipsarum rerum unionibus aut habitudinibus, in quibus talia denominativa nomina fundatur, quae non sunt opera rationis."
} 
Here Suárez rejects the anti-realist conception of denominations. The reason for doing so is that when we talk about denominations, "we are concerned with the unions and relations of things themselves, in which such denominative names are grounded." As I understand him, what Suárez means here is that when we talk about denominations, we are talking about denominative forms and their relations to denominated subjects. Because Suárez identifies denominations with real entities, I will call his conception of denominations the 'realist conception'.

Let's pause to take stock. According to the semi-extrinsic denomination view, truth is a denomination that is partly intrinsic and partly extrinsic to a true proposition. This raises the question, what sort of thing is a denomination? As we have just seen, there are two conceptions of denominations in the early modern scholastic literature: the antirealist conception, and the realist conception. On the anti-realist conception, denominations are mind-dependent, linguistic phenomena. When this view is paired with the semi-extrinsic denomination view of truth, it entails the claim that truth is a minddependent, linguistic phenomenon. On the realist conception, denominations are real entities in which denominative names are grounded. When this conception is paired with the semi-extrinsic denomination view of truth, it entails that truth is a real entity in which the denominative name, 'true', is grounded. The question now is, which conception of denominations is supposed to be paired with the semi-extrinsic denomination view of truth?

Oviedo and Arriaga, the standard-bearers of the semi-extrinsic denomination view, both accept the realist conception of denominations. Oviedo weighs in on the debate between Vázquez and Suárez concerning the ontological status of extrinsic denominations, and he sides with Suárez:

I agree with Father Suárez [...] and many others: every extrinsic denomination coming from a real form, whether physical or intentional, is real, mixed with no being of reason. I prove this conclusion. A denomination is taken from a denominating form; therefore, if the form is real, the denomination will be real. ${ }^{21}$

\footnotetext{
${ }^{21}$ Oviedo, Tomus II philosophiae, 361-362.3: "Sentio cum P. Soar. [...] \& aliis plurimis omnem denominationem extrinsecam provenientem a forma reali, sive physica, sive intentionali, esse realem
} 
Arriaga too weighs in briefly on the controversy over the ontological status of extrinsic denominations, and he takes the Suárezian line that extrinsic denominations are real entities. In the sixth edition of his Cursus philosophicus, Arriaga explicitly rejects the view that truth is a being of reason. ${ }^{22}$ It therefore appears that the semi-extrinsic denomination view of truth is supposed to be paired with a realist conception of denominations. If so, then the semi-extrinsic denomination view of truth amounts to the following:

The Semi-Extrinsic Denomination View: Truth is a real entity that is (i) partly intrinsic and partly extrinsic to a true proposition, (ii) in which the denominative name, 'true', is grounded.

But what sort of entity is partly intrinsic and partly extrinsic to a true proposition? As I will now explain, advocates of the semi-extrinsic denomination view of truth conceive of truth as the mereological sum of a proposition and its intentional object. It is this mereological sum that is partly intrinsic and partly extrinsic to a true proposition. Moreover, the idea that truth is a mereological sum of a true proposition and its intentional object allows us to see how the notion of a truthmaker is related to the semiextrinsic denomination view of truth.

\section{Truth as a Mereological Sum, Truthmakers as Parts of Truth}

Giuseppe Polizzi, an opponent of the semi-extrinsic denomination view, reads both Oviedo and Arriaga as endorsing the claim that truth is a mereological sum of a proposition and its intentional object. In his discussion of truth, Polizzi writes,

The first conclusion is that the object is not an intrinsic part composing formal truth and falsity. This is against Arriaga [...] Oviedo [...] and other contemporaries who think that truth is composed of two intrinsic parts, one of which is intrinsic to the proposition-indeed, it is the proposition itself-insofar as it affirms, e.g., Peter's running, and the other part is

absque ulla mixtura entis rationis. Probo hanc conclusionem: denominatio sumitur a forma denominante; ergo si forma est realis, denominatio erit realis."

${ }^{22}$ Arriaga, Cursus philosophicus iam noviter auctus, $224.11 \mathrm{ff}$. 
extrinsic to the proposition but intrinsic to the truth, and it is the object existing in the way in which it is affirmed by the proposition. ${ }^{23}$

According to this passage, Arriaga's view is that truth is the mereological sum of a true proposition and its intentional object. Indeed, Arriaga speaks several times of the "parts" of truth and speaks of truth as being "composed." 24 Other early modern scholastics make similar statements about the "parts" of truth. Richard Lynch says that truth is an "aggregate" of a proposition and its object. ${ }^{25}$ Pedro Hurtado de Mendoza tells us, "In Suárez's opinion, the object is a part of truth. ${ }^{, 26}$ Luis de Losada suggests that the this view eventually became the "common" Jesuit view of truth:

The common opinion in our School is that truth consists in a complex of an act and an object, in such a way that by the name 'truth' an act is implied [importetur] directly, and an object indirectly, and so the denomination 'true' is partly intrinsic, partly extrinsic to the act: intrinsic insofar as it involves the act itself, extrinsic insofar as it implies the object. ${ }^{27}$

Earlier we saw that on the semi-extrinsic denomination view, truth is conceived as a real entity that is partly intrinsic and partly extrinsic to a true proposition. In light of the above passages about the parts of truth, we can now state what sort of real being is partly intrinsic and partly extrinsic to a true proposition. To be partly intrinsic to something is to have a part that is intrinsic to that thing. The truth of ' $p$ ' is partly intrinsic to ' $p$ ' insofar as one of its parts - ' $p$ ' itself - is intrinsic to 'p'. Further, to be partly extrinsic to something is to have a part that is extrinsic to that thing. The truth of ' $p$ ' is partly extrinsic to ' $p$ ' insofar as one of its parts-its intentional object-is extrinsic to 'p'. Hence, the mereological sum of ' $p$ ' and its intentional object is partly intrinsic to 'p' insofar as one of its parts is intrinsic to 'p', and it is partly extrinsic to 'p' insofar as one of its parts is

\footnotetext{
${ }^{23}$ Polizzi, Philosophicarum disputationum tomus tertius, 366.33: "Prima conclusio: Obiectum non est pars intrinsece componens veritatem \& falsitatem formalem. Est contra Arriagam loco citato subsect. 5, Oviedum ibi s. 3, \& alios Recentiores existimantes veritatem ex duplici parte sibi intrinseca componi, quarum una est intrinseca propositioni, immo est ipsa propositio, quatenus affirmat V.G. cursum Petri; altera vero extrinseca propositioni, licet intrinseca veritati \& est ipsum obiectum eo modo existens, quo per propositionem affirmatur."

${ }^{24}$ See Cursus philosophicus, $172.37,39$.

${ }^{25}$ Lynch, Universa philosophia scholastica tomus primus, 361.6.

${ }^{26}$ Hurtado, Universa philosophia, 576.22: "In sententia P. Suárez obiectum est pars veritatis."

${ }^{27}$ Losada, Cursus philosophici prima pars, 231.2 (erroneously marked p. '131'): "Sententia in Schola nostra communis Veritatem stare dicit in complexo actus \& obiecti, ita ut hoc nomine Veritas importetur actus in recto, obiectum in obliquo, priondeque denominationem veri esse partim intrinsecam, partim extrinsecam actui, intrinsecam prout involvit actum ipsum, extrinsecam prout importat obiectum.”
} 
extrinsic to ' $p$ '. If all this is correct, talk about the parts of truth is in keeping with the semi-extrinsic denomination view of truth.

The mereological sum of a proposition and its object exists if and only if both the proposition and its object exists. It follows that, on the semi-extrinsic denomination view, a proposition is true if and only if its object exists. Arriaga himself suggests as much in several passages, including the following:

For a proposition to be true is nothing other than for it to affirm [for example] Peter's running, and for this to exist in reality. But this implies two things: the proposition and the existence of the object [my emphasis]. ${ }^{28}$

Similarity is not a true relation. It is the coexistence of two terms that are naturally of the same species or genus. I say the same thing about Truth, which is nothing other than a denomination taken from the affirmation of the object and the existence of the object affirmed [my emphasis]. ${ }^{29}$

In both of these passages Arriaga claims that a proposition (affirmation) is true if and only if both the proposition (affirmation) and its object exists. This will be an important claim going forward, so it will be useful to give it a name. I will call it 'Truth':

Truth: A proposition ' $p$ ' is true if and only if ' $p$ ' exists and its object exists.

Here a question may arise as to the ontological status of the objects of false propositions. It follows from Truth that if a proposition is false, then its object does not exist. But how can a proposition have an object that does not exist? The answer, in short, is that the objects of false propositions have objective being, a kind of being that falls short of existence. ${ }^{30}$ (Someone might now worry that if the objects of false propositions have objective being, then they too can enter into composition relations with propositions. The unwelcome result would be that every proposition is trivially true, just in virtue of having

\footnotetext{
${ }^{28}$ Cursus philosophicus, 170.27: "Propositionem esse veram, nihil aliud est, quam ipsam affirmare cursum Petri, \& hunc dari a parte rei: sed hoc dicit duo, \& propositionem \& existentiam obiecti."

${ }^{29}$ Cursus philosophicus, 172.36: "Similitudinem non esse veram relationem, sed coexistentiam duorum extremorum in eiusdem speciei aut generis natura. Idem dico de Veritate, quae nihil aliud est quam denominatio desumpta ex affirmatione obiecti, \& existentia obiecti affirmati."

${ }^{30}$ See Arriaga, Cursus philosophicus, 783.8 .
} 
an object. I have not seen any early modern scholastics respond to this worry, but one available and in my view plausible move is to restrict composition to things that exist.)

As we have seen, the object of a true proposition is literally a part of that proposition's truth (when the object exists; henceforth I drop this qualifier for the sake of brevity). This allows us to see how the semi-extrinsic denomination view of truth is related to the early modern scholastic conception of a truthmaker. The truthmaker of a proposition is conceived of as part of that proposition's truth. This idea is expressed in the following passage by Benedictis:

And so the object is extrinsic to the cognition, but it is not extrinsic to truth. Since truth is the commensuration of both the object and the act, it intrinsically and constitutively includes [importat] both the object and the act: the object as truthmaker [verificativum] and the act as made-true [verificatum]. ${ }^{31}$

Here Benedictis endorses the semi-extrinsic denomination view of truth, and he identifies one part of truth - the intentional object — as the truthmaker of a true proposition. In his discussion of future contingent truths, Maximus Mangold writes,

Further, it is asked in virtue of what are [future contingent truths] true or false? Or, what is their truthmaker, as they say in the school [...] Here we are only inquiring after that part of truth, or the truthmaker inadequately taken, distinct from the proposition, in virtue of which the proposition is formally and immediately denominated 'true', and which they call the objective truthmaker. ${ }^{32}$

In another smoking gun passage from an anonymous disputation, On the Object and Truthmaker of Propositions, probably dating from the late $17^{\text {th }}$ century, an anonymous author draws a connection between truthmaking and the semi-extrinsic denomination view of truth as follows:

\footnotetext{
${ }^{31}$ Benedictis, Philosophia peripatetica, 569: "Itaque ut obiectum sit extrinsecum cognitioni, non tamen est extrinsecum veritati, quae cum sit commensuratio duorum, utrumque intrinsece, \& constitutive importat, obiectum ut verificativum, actum ut verificatum."

${ }^{32}$ Mangold, Philosophia recentior, vol. 1, 96.98: "Ulterius quaeritur per quid verae aut falsae sint? Sive, quodnam sit illarum verificativum, ut loquuntur scholae [...] Solum hic inquiritur illa pars veritatis, seu verificativum inadaequate sumptum distinctum ab ipsa propositione, per quod haec formaliter \& immediate denominatur vera, quodque vocant verificativum obiectivum."
} 
The formal truthmaker of any judgment is that by which the act is rendered formally true [...] For example, the formal truthmaker of this judgment, 'Peter is possible', is the possibility with which the truth of that act is partially identified [my emphasis]. ${ }^{33}$

This passage occurs in the beginning of a section on truthmaking; our anonymous author explains the concept of a truthmaker using what appears to be the semi-extrinsic denomination view of truth: truthmakers are partly identical with (or part of) truth itself. Indeed, later in the same disputation the author claims, "Truth consists in the existence of the act and the existence of the object." ${ }^{34}$ As with the authors mentioned above, the anonymous author appears to endorse the semi-extrinsic denomination view of truth, and he explains truthmakers as partly constitutive of truth itself. My suggestion, therefore, is that for many early modern scholastics a truthmaker is literally a maker of truth insofar as it is a part of truth. It might help to think of truthmakers on analogy with the substantial form of a human; a human's substantial form is part of the human, and it is that part in virtue of which she is human. Similarly, a truthmaker is part of the truth of a proposition, and it is that part in virtue of which the proposition is true.

It is worth noting in passing the similarity of this conception of truthmaking with the contemporary conception of truthmaking as an internal relation. ${ }^{35}$ An internal relation is one that obtains in virtue of the non-relational, intrinsic features of the relata. To use John Heil's example, 'If you have Simmias' being six feet tall and Socrates' being five feet tall, you thereby have Simmias' being taller than Socrates" (Heil 2012: 156). Internal relations are said to be "no addition to being" insofar as the only entities needed to make it true that Simmias is taller than Socrates, for example, are the heights of Simmias and Socrates. ${ }^{36}$ (If you think that height is not an entity, you can cook up your own example using the coexists relation.)

According to Armstrong and Heil, the truthmaking relation is an internal relation. Heil writes:

\footnotetext{
33 Anonymous, Disputatio de obiecto et verificativo propositionum, f. $217 \mathrm{v}$ : "Verificativum formale alicuius iudicii est illud a quo actus redditur verus formaliter [...] Exempli gratia, verificativum formale huius iudicii 'Petrus est possibilis' est possibilitas, cum qua inadaequate identificatur istius iudicii veritas."

${ }^{34}$ Anonymous, Disputatio de obiecto et verificativo propositionum, f. $221 \mathrm{v}$ : "Veritas stat in existentia actus et existentia obiecti."

${ }^{35}$ Thanks to John Heil for pointing this out.

${ }^{36}$ For the "no addition of being" claim, see Armstrong 2004: 9.
} 
I follow Armstrong $(2004,9)$ in regarding the truthmaking relation as an internal relation. If you have a truth-bearer-a judgment that $p$, for instance-and you have its being the case that $p$, you have truthmaking, you have a judgment's being true, you have the judgment's being made true by its being the case that $p$. [Heil 2012: 156]

It should be clear from the foregoing discussion that advocates of the semi-extrinsic denomination view would (or ought to) endorse the idea that, if you have a proposition and its intentional object, you have that proposition's truth. It is noteworthy that Arriaga himself argues that categorical relations are intrinsic relations in Heil's and Armstrong's sense, and he sometimes suggests that truth is a categorical relation. ${ }^{37}$ I think it would not be a stretch to say that for Arriaga truth is an internal relation, and that he would cash out the "no addition in being" claim by saying that internal relations generally are mereological sums of their relata. ${ }^{38}$ However, some caution is warranted here: early modern scholastics who endorse the semi-extrinsic denomination view of truth rarely speak of truth as a relation. I suspect they did not want to pin the semi-extrinsic denomination view of truth to a controversial view of relations.

\section{The Standard Account of Truthmaking}

We are now in a position to reconstruct an early modern scholastic account of truthmaking. I will proceed by taking into consideration questions of importance to contemporary truthmaker theorists: Which truths need truthmakers? Do truthmakers necessitate truths? Must truths be about their truthmakers? Is truthmaking crosscategorial? Is truthmaking "many-many"? I call the following account of truthmaking the "standard account" because some early modern scholastics deviate from its details in ways that I will mention in the conclusion.

The foregoing remarks about truth are fully general. More specifically, Truth-the claim that a proposition ' $p$ ' is true if and only if ' $p$ ' exists and its object exists-is fully

\footnotetext{
${ }^{37}$ For Arriaga's view of relations, see Cursus philosophicus, 153.41ff. and Penner (2012). Arriaga assimilates his view of truth to his view of similarity in Cursus philosophicus 172.36, and he speaks of the relation of true at 166.3. Thanks to Sydney Penner for pressing me to think more about the relationship between Arriaga's view of relations on the one hand and his view of truth on the other. There is probably much more to be said on this score.

${ }^{38}$ Arriaga suggests that relations have parts at Cursus philosophicus 153.41-8.
} 
general. It follows that every truth has a truthmaker. This is the doctrine contemporary philosophers call "Truthmaker Maximalism".

Several passages from the primary literature indicate commitment to Truthmaker Maximalism. For example, Silvestro Mauro writes:

In all propositions some existence, or the proposition's ultimate truthmaking actuality [actualitas verificativa], is affirmed [my emphasis]. ${ }^{39}$

Mauro here claims that every proposition affirms the existence of something. Mauro calls the object affirmed by a proposition a 'truthmaking actuality', presumably, because a proposition is true if and only if what it affirms to exist does exist. Hence, on Mauro's view every truth has a truthmaker. Further, Nicholas Martinez argues at length against the following principle: "Every true proposition, in order to be true, requires a truthmaker present with itself and really existing." ${ }^{40}$ The fact that Martinez argues at length against this principle suggests that the principle enjoyed some currency among his contemporaries. Finally, the author of an anonymous disputation tells us, "every act that is strictly true in the present ought to have a truthmaker strictly existing in the present." ${ }^{\prime 11}$ The author of this passage is actually committed to something stronger than Truthmaker Maximalism, for he says that every proposition that is true now has a present truthmaker. At any rate, it appears that several early modern scholastics are committed to Truthmaker Maximalism.

Truthmaker Maximalism is controversial among contemporary philosophers. Peter Simons calls Truthmaker Maximalism "the most tendentious of Armstrong's general truthmaking principles", 42 and Julian Dodd regards truthmaker theory itself as "a superstition". ${ }^{43}$ I presume this is a colorful way of saying that the idea that truths have truthmakers is unmotivated. Far from being a superstition, the early modern scholastic

\footnotetext{
${ }^{39}$ Mauro, Liber secundus, 170: "In omnibus propositionibus affirmatur aliqua existentia, sive ultima actualitas verificativa propositionis."

${ }^{40}$ Martinez, Deus sciens, 73: "Omnis propositio vera, ut vera sit, requirit verificativum sui actu praesens, \& realiter existens."

${ }^{41}$ Anon., Disputatio de obiecto et verificativo propositionum, f. $220 \mathrm{v}$ : "Omnis actus de praesenti stricte verus debet habere verificativum stricte de praesenti existens."

${ }^{42}$ Simons, "Negatives, Numbers, and Necessity: Some Worries About Armstrong's Version of Truthmaking," 254.

${ }^{43}$ Julian Dodd, An Identity Theory of Truth, 9; see also Julian Dodd, "Is Truth Supervenient on Being?" 69-85.
} 
commitment to Truthmaker Maximalism is straightforwardly entailed by the semiextrinsic denomination view of truth. In the dialectical context of early modern scholasticism, those who wish to restrict the truthmaker principle must earn the right to do so by offering a theory of truth that does not entail Truthmaker Maximalism. Perhaps the primary motivation for rejecting Truthmaker Maximalism in the contemporary literature is that it seems to have extravagant ontological implications. It is worth noting that early modern scholastics were quite aware of the ontological implications of Truthmaker Maximalism. Commitment to this doctrine sparked debates about truthmakers for negative truths, tensed truths, and modal truths.

Many contemporary truthmaker theorists think that truthmakers necessitate truths, but there is some disagreement over how to formulate this claim. ${ }^{44}$ If necessitation is conceived as follows,

T necessitates the truth of ' $p$ ' $=_{\mathrm{df}}$ Necessarily, if T exists, then ' $p$ ' is true,

then advocates of the semi-extrinsic denomination view of truth are likely to say that truthmakers do not necessitate truths. The reason is that the above formulation of necessitation says nothing about truth-bearers, whereas early modern scholastics typically insist that there is truth only if there is a truth-bearer. Truth is not merely a function of what the world is like, but it is also a function of what truth-bearers are like.

As we have seen, advocates of the semi-extrinsic denomination view are committed to Truth:

Truth: A proposition 'p' is true if and only if 'p' exists and its object exists.

If we assume that a theory of truth is necessarily true if true at all, we can infer that advocates of the semi-extrinsic denomination view are committed to the modalized version of Truth:

\footnotetext{
${ }^{44}$ For contemporary discussion see Bigelow 1988: 126-127; Fox 1987: 189; Beebee and Dodd 2005: 2; Rodriguez-Pereyra 2006: 18; Merricks 2007: 12-13; Armstrong 2004: 5-6; Restall 1996; Cameron 2005; Heil 2000; Schaffer 2010: 320.
} 
$\square$ Truth: Necessarily, a proposition 'p' is true if and only if 'p' exists and its object exists.

Reading the bi-conditional in $\square$ Truth from right to left, we get

Necessarily, if a proposition 'p' exists and its object exists, then 'p' is true.

If this is what is meant by the claim that truthmakers necessitate truths, then advocates of the standard account would agree that truthmakers necessitate truths.

Some contemporary philosophers claim that truthmaking is subject to a relevance constraint. ${ }^{45}$ To see why, suppose our account of truthmaking is as follows:

Trivial Truthmaker: T makes ' $p$ ' true if and only if, necessarily, if $T$ and ' $p$ ' exist, then ' $p$ ' is true.

Trivial Truthmaker is so-called because it allows trivial truthmakers. For example, it is necessarily the case that if my left ear exists and the proposition that goes by the name 'Gödel's second incompleteness theorem' exists, then Gödel's second incompleteness theorem is true. It follows from Trivial Truthmaker that my left ear makes Gödel's second incompleteness theorem true. This result seems wrong, however, because my left ear is irrelevant to Gödel's second incompleteness theorem. In order to block this result, some philosophers want to subject truthmaking to a relevance constraint.

The relevance constraint is not only built into but is also explained by Truth. According to Truth, the truthmaker for ' $p$ ' is the intentional object of ' $p$ '-i.e., what ' $p$ ' is about. Hence, truthmakers are relevant to truths insofar as truths are about their truthmakers, and Gödel's second incompleteness theorem is not made true by my left ear because Gödel's second incompleteness theorem is not about my left ear.

\footnotetext{
${ }^{45}$ For relevant contemporary discussion see Restall 1996: 333-334; Armstrong 2004: 10-12; RodriguezPereyra 2006: 187; Merricks 2007: 22-34.
} 
Many early modern scholastics explicitly endorse this idea that truths are about their truthmakers, which plays an important dialectical role in $17^{\text {th }}$-century ontological debates about truthmakers for various sorts of truths. For example, Francisco Peinado:

It seems well known from the terms themselves that no internal or external speech and no act of the intellect is rendered true by something that it does not say, by an object that it does not represent. For who would say that this act, 'Peter runs', is formally made true by the existence of God or by any other entity distinct from the running of Peter, which the act represents? ${ }^{46}$

However, it is worth noting that in the latter half of the $17^{\text {th }}$-century some philosophers, including Peinado, began to draw a distinction between so-called formal truthmakers and illative or radical truthmakers. The author of the anonymous disputation mentioned above draws the distinction as follows:

The formal truthmaker of some judgment is that by which the act is formally rendered true. The illative truthmaker is whatever is connected with the fact that the proposition is true, but which is not constitutive [of the proposition's being true]. For example, the formal truthmaker of this act, 'Peter is possible', is the possibility with which the truth of that judgment is partially identified. The illative truthmakers are God's necessary predicates, or whatever else is connected with the fact that the object of the aforesaid proposition is as it is said to be by the act. ${ }^{47}$

As this passage suggests, the primary difference between formal truthmakers and illative truthmakers is that formal truthmakers are constitutive of the truth of a proposition, whereas illative truthmakers are merely "connected" to the truth of a proposition. To be connected with the truth of a proposition in this case is merely to necessitate the truth of the proposition. Truths need not be about their illative truthmakers, as Madritano tells us in the following passage:

\footnotetext{
${ }^{46}$ Peinado, De anima, 265.32: "Nam ex terminis ipsis videter notum quod nulla loquutio interna aut externa nullusque actus intellectus redditur verus ab eo quod ipse non dicit, \& ab obiecto quod non repraesentat. Nam quis dicat hunc actum: Petrus currit verificari formaliter ab existentia Dei, aut ab alia entitate distincta a cursu Petri, quem repraesentat actus?" See also Disputationes in octo libros physicorum Aristotelis, $175 b .8$.

${ }^{47}$ Anonymous, Disputatio de obiecto et verificativo propositionum, f. $217 \mathrm{v}$ : "Verificativum formale alicuius iudicii est illud a quo actus redditur verus formaliter. Verificativum illativum est quodlibet connexum cum eo quod propositio sit vera, quod tamen non sit constitutivum. Exempli gratia, verificativum formale huius iudicii 'Petrus est posibilis' est posibilitas, cum qua inadaequate identificatur istius iudicii veritas; illativum sunt praedictata necessaria Dei, vel quodlibet aliud cum eo connexum quod obiectum praedictae propositionis se habeat sicuti per actum enuntiatur."
} 
An objective, formal, and immediate truthmaker of any act is that which the act expresses [enunciat]. For if it is not expressed by the act, it will be at most an illative truthmaker. ${ }^{48}$

So although most early modern scholastic truthmaker theorist would say that truths are about their formal truthmakers, they sometimes carve out conceptual space for a kind of truthmaker that is not the intentional object of the truth it makes true.

Contemporary philosophers widely agree that truthmaking is cross-categorial in the sense that truths and truthmakers typically belong to distinct ontological categories (Armstrong 2004: 5; Rodriguez-Pereyra 2006: 188). Many early modern scholastics explicitly acknowledge that truths and truthmakers typically belong to distinct ontological categories. Giattini, for example, observes, "The object [of a cognition] is often a substance, and the cognition is always an accident. ${ }^{, 49}$ Here Giattini is conceiving of truth-bearers - i.e., acts of cognition - as accidents of the mind. Because truthmakers are often not accidents, he would agree with contemporary truthmaker theorists that truthmaking is cross-categorial.

Truthmaker theorists often claim that the truthmaker relation is 'many-many'. 50 What 'many-many' means in this context is most easily grasped by way of example. First, Truthmaker theorists observe that one truthmaker can make true many propositions taken individually (henceforth I drop the qualification 'taken individually'). If T makes ' $p$ ' true, then $\mathrm{T}$ also makes ' $\mathrm{p} \vee \mathrm{q}$ ' true. The point here is that there is no need to posit unique truthmakers for ' $p$ ' and ' $p \vee q$ '; the truthmaker for a disjunct is the truthmaker for the disjunction. Second, many entities taken individually can make a single proposition true. For example, Smith and Jones each make it true that there is a human. So there are two ways in which truthmaking is said to be 'many-many': first, one truthmaker can make many truths true; second, one truth can have multiple truthmakers. Is truthmaking 'many-many' in either of these ways on the standard account?

So long as distinct truths can share an intentional object and consequently a truthmaker, the standard account is compatible with the idea that one truthmaker can

\footnotetext{
${ }^{48}$ Madritano, Prodromus, 775.52: "Verificativum obiectivum, formale, ac immediatum cuiuslibet actus est illud quod actus enunciat. Si enim per actum non enunciatur erit ad summum verificativum illativum."

${ }^{49}$ Giattini, Logica, 447: "Obiectum saepe est substantia, \& cognitio semper est accidens."

${ }^{50}$ For more on the 'many-many' claim, see Armstrong 2004: 16-17; Merricks 2007: 4; Mulligan, Simons, and Smith 1984: 289; Rodriguez-Pereyra 2006: $§ 6$.
} 
make many truths true. Indeed, Silvestro Mauro thinks that God is the single truthmaker for a variety of distinct propositions, including 'God exists', 'Man is a rational animal', 'Horse is a hinnible animal', and 'Peter is possible'. ${ }^{51}$ Mauro's position might seem odd in light of the requirement that truths be about their truthmakers. Indeed, one important objection to Mauro's view is precisely that propositions such as 'Man is a rational animal' do not appear to be about God. Mauro is aware of this kind of objection and responds by trying to make conceptual space for the claim that every necessary proposition is, in a sense, about God. ${ }^{52}$

Although Truth is compatible with the idea that one truthmaker can make true many truths, it seems to presuppose that each proposition has only one intentional object. Since the truthmaker of a proposition is its intentional object, it follows that each true proposition has exactly one truthmaker. There is some textual evidence for this claim. In one passage, Giattini tells us,

One must explain what it is for a proposition to be true, and what a proposition requires on the part of the object in reality in order to be true. This I call a 'truthmaker'.

Here Giattini describes a truthmaker as that which is required for the truth of a proposition. If a truthmaker for ' $p$ ' is something required for the truth of ' $p$ ', it follows that ' $p$ ' has only one truthmaker, for if ' $p$ ' could have multiple truthmakers, each of which would be sufficient for the truth of the proposition, then it would not be the case that each truthmaker is required for the truth of the proposition. To illustrate, suppose that ' $p \vee q$ ' has two truthmakers, the fact that $p$ and the fact that $q$. On that supposition, the fact that $p$ could fail to exist, and yet ' $p \vee q$ ' would still be true, since the fact that $q$ would still exist. On the supposition that ' $p \vee q$ ' has two truthmakers, neither truthmaker is required for the truth of ' $p \vee q$ '. But because Giattini clearly states that the truthmaker for a proposition is required for the truth of that proposition, it seems Giattini cannot allow that truths have multiple truthmakers.

\footnotetext{
${ }^{51}$ Mauro, Liber secundus, 165a.6.

${ }^{52}$ Mauro, Liber secundus, 169b.5-173.8.

${ }^{53}$ Giattini, Logica, 292: "Debet assignari quid sit propositionem esse veram, \& quid requirat ex parte obiecti realiter ad hoc ut sit vera, quod appello verificativum."
} 
Is this a problem for the standard account of truthmaking? Not obviously. An advocate of the standard account might distinguish between a proposition's immediate and ultimate truthmakers, where immediate truthmakers are reducible to or realized by ultimate truthmakers. ${ }^{54}$ For example, suppose that an advocate of the standard account claims that 'Obama exists or Bush exists' is made true by a disjunctive state of affairs. Let us write $\{$ Obama $\vee$ Bush $\}$ for the disjunctive truthmaker for 'Obama exists or Bush exists'. It is open to an advocate of the standard account to claim that $\{$ Obama $\vee$ Bush $\}$ is reducible to or realized by both Obama and Bush, the ultimate truthmakers for 'Obama exists or Bush exists'. In this way, the standard account can be made to accommodate the intuitions behind the widespread contemporary endorsement of the claim that truthmaking is many-many. To be sure, the strategy of distinguishing between formal and ultimate truthmakers is not explicitly advocated in the early modern scholastic literature. Nonetheless, such a strategy could help make sense of the view, apparently entailed by Truth, that every truth has only one truthmaker.

\section{Conclusion}

The foregoing is the account of truthmaking behind many early modern scholastic uses of the term verificativum. It is important to note that I have not told the whole story of the early modern scholastics on truthmaking; I have told what I take to be one important part of the story. I want to end by indicating how some early modern scholastics deviate from what I have called the standard account of truthmaking.

Some early modern scholastics reject the idea that every truth is made true by something that exists, and they try to make conceptual space for the idea of truthmakers that do not exist. In the debate about truthmakers for tensed truths, for example, some philosophers maintain that future (past) tensed truths can be made true by non-existent, future (past) objects. ${ }^{55}$ In the debate about truthmakers for negative truths, some maintain

\footnotetext{
${ }^{54}$ I vaguely recall having heard Kit Fine draw this distinction in a talk. For formal details relevant to immediate truthmaking, see Van Fraassen 1969; Fine 2012.

${ }^{55}$ E.g., Peinado, De anima, 387.42 .
} 
that there is a sense in which negative truths are made true by non-existent objects. ${ }^{56}$ In order to make sense of this view, they introduce a distinction between "truthmakers in the positive sense" and "truthmakers in the negative sense". Truthmakers in the positive sense are truthmakers as conceived on the standard account given above. Truthmakers in the negative sense are objects that make a proposition true by failing to exist. For example, Pegasus is the truthmaker in the negative sense for 'Pegasus does not exist'. The idea is that Pegasus, by not existing, makes it true (in the negative sense) that Pegasus does not exist. The task for those who endorse these deviations from the standard account is to reconcile their views of truth with their views of truthmaking. The philosophers in question are quite aware of the dialectical situation, and they attempt to provide theories of truth compatible with their non-standard accounts of truthmaking. The question whether or not these efforts are successful deserves a paper of its own.

\section{Primary Sources}

Anonymous. Disputatio de objecto et verificativo propositionum. Madrid: Biblioteca de la Real Academia de la Historia, Ms. 9/3081, f. 213r-223r.

Arriaga, Rodrigo de. (1639) Cursus philosophicus. Paris.

- (1669) Cursus philosophicus iam noviter maxima ex parte auctus. Lyon.

Benedictis, Giovanni Battista de. (1688) Philosophia peripatetica tomis quinque

comprehensa: tomus primus, logica. Naples.

Giattini Sr., Giovannbattista. (1651) Logica. Rome.

Hurtado de Mendoza, Pedro. (1624) Universa philosophia. Lyon.

Izquierdo, Sebastián. (1659) Pharus scientiarum. Lyon.

Losada, Luis de. (1747) Cursus philosophici prima pars. Salamanca.

Lynch, Richard. (1654) Universa philosophia scholastica tomus primus. Lyon.

Madritano, Juan de Ulloa. (1711) Prodromus seu prolegomena ad scholasticas

disciplinas. 1st Edition. Rome.

Mangold, Maximus. (1765) Philosophia recentior. Vol. 1. Ingolstadt.

\footnotetext{
${ }^{56}$ Peinado, De anima, 266.32. See also Madritano, Prodromus, 776.53. For more on the debate about truthmakers for negative truths, see Schmutz 2007; Embry forthcoming.
} 
Martinez, Nicholas. (1738) Deus sciens sive de scientia Dei. Venice.

Mauro, Silvestro. (1670) Quaestionum philosophicarum liber secundus. $2^{\text {nd }}$ Edition. Rome.

Oviedo, Francisco. (1663) Tomus II philosophiae. $3^{\text {rd }}$ Edition. Lyon.

Peinado, Ignacio Francisco. (1680) Disputationes in octos libros physicorum Aristotelis. Alcalá.

—. (1762) Disputationes in tres libros Aristotelis de anima, opus posthumum. Alcalá.

Polizzi, Giuseppe. (1675) Philosophicarum disputationum tomus tertius. Palermo.

Suárez, Francisco. (1856-1878) Opera omnia. 28 vols. Paris: Luis Vivès.

Vázquez, Gabriel. (1631a) Commentariorum ac disputationum in primam partem Sancti Thomae tomus primus. Lyon.

-. (1631b) Commentariorum ac disputationum in primam partem Sancti Thomae tomus secundus. Lyon.

\section{Contemporary References}

Armstrong, David. (2004) Truth and Truthmakers. Cambridge: Cambridge University Press.

Beebee, Helen and Julian Dodd. (2005) Truthmakers: The Contemporary Debate. New York: Oxford University Press.

Bigelow, John. (1988) The Reality of Numbers. New York: Oxford University Press.

Cameron, Ross. (2005) 'Truthmaker Necessitarianism and Maximalism'. Logique et Analyse, 48, nn. 189-192, 43-56.

Dodd, Julian. (2000) An Identity Theory of Truth. $1^{\text {st }}$ Edition. Basingstoke: Macmillan.

Doyle, John. (1984) 'Prolegomena to a Study of Extrinsic Denominationin the Work of Fracisco Suárez, S.J.' Vivarium, 22, no. 2, 121-156.

Doyle, John. (1995) 'Another God, Chimerae, Goat-Stags, and Man-Lions'. Review of Metaphysics, 48, no. 4, 771-808.

Embry, Brian. (forthcoming) 'An Early Modern Scholastic Theory of Negative Entities: Thomas Compton Carleton on Lacks, Negations, and Privations'. British Journal for the History of Philosophy. 
Fine, Kit. (2012) 'Counterfactuals Without Possible Worlds'. The Journal of Philosophy, 109 , no. 3, 221-246.

Fox, John. (1987) 'Truthmaker'. Australasian Journal of Philosophy, 65, no. 2, 188-207. Gracia, Jorge, and Daniel Novotny. (2011) 'Fundamentals in Suarez's Metaphysics'. In Daniel Schwartz (ed.), Interpreting Suárez, (Cambridge: Cambridge University Press), pp. 19-38.

Heil, John. (2000) 'Truth Making and Entailment'. Logique et Analyse, 43, no. 169-170, 231-242.

Heil, John. (2012) The Universe As We Find It. Oxford: Clarendon Press.

Merricks, Trenton. (2007) Truth and Ontology. New York: Oxford University Press.

Mulligan, Kevin, Peter Simons, and Barry Smith. (1984) 'Truth-Makers'. Philosophy and Phenomenological Research, 44, no. 3, 287-321.

Penner, Sydney. (2012) 'Rodrigo de Arriaga on Relations'. The Modern Schoolman 89, $25-46$.

Ramelow, Tilman. (1997) Gott, Freiheit, Weltenwahl. Die Metaphysik der Willensfreiheit zwischen Antonio Pérez S.J. (1599-1649) und G.W. Leibniz (1649-1716). Leiden: Brill.

Restall, Greg. (1996) 'Truthmakers, Entailment, and Necessity'. Australasian Journal of Philosophy, 74, no. 2, 331-340.

Rodriguez-Pereyra, Gonzalo. (2006) 'Truthmakers'. Philosophy Compass, 1, no. 2, 186200.

Schaffer, Jonathan. (2010) 'The Least Discerning and Most Promiscuous Truthmaker'. The Philosophical Quarterly, 60, no. 239, 307-324.

Schmutz, Jacob. (2007) 'Réalistes, nihilistes et incompatibilistes: le débat sur les negative truthmakers dans la scolastique Jésuite Espagnole'. In J. Laurent (ed.), Dire le Néant, (Caen: Presses Universitaires de Caen [Cahiers de philosophie de l'Université de Caen, no. 43], pp. 131-178.

Schmutz, Jacob. (2011) 'Verificativum'. In D. Calma, I. Atucha, C. König-Pralong and I. Zavettero (ed.), Mots médiévaux offerts à Ruedi Imbach, (Turnhout: Brepols), pp. 739-748. 
Shields, Christopher. (2012 ) 'Shadows of Beings: Francisco Suárez's Entia Rationis'. In Benjamin Hill and Henrik Lagerlund (ed.), The Philosophy of Francisco Suárez, (Oxford: Oxford University Press), pp. 57-74.

Simons, Peter. (2005) 'Negatives, Numbers, and Necessity: Some Worries About Armstrong's Version of Truthmaking'. Australasian Journal of Philosophy, 83, no. 2, 253-261.

Van Fraassen, Bas. (1969) 'Facts and Tautological Entailments'. The Journal of Philosophy, 66, no. 15, 477-487. 